\title{
Infant mastocytosis: Urticaria pigmentosa an entity to know
}

Sara Oukarfi*, Selma Benkirane, Sara Elloudi, Hanae Baybay, Fatima Zahra Mernissi

Department of dermatology and venerology, hospital university Hassan II, Fez, Morocco.

*Corresponding author: Sara Oukarfi, Department of dermatology and venerology, hospital university Hassan II, Fez, Morocco.

Received date: February 17, 2020; Accepted date: March 06, 2020; Published date: March 13, 2020

Citation: Oukarfi S, Benkirane S, Elloudi S, Baybay H, Fatima Z Mernissi (2020). Infant mastocytosis: Urticaria pigmentosa an entity to know. Journal of Dermatology and Dermatitis.5 (1); Doi:10.31579/2578-8949/63

Copyright: (C) 2020 Sara Oukarfi, This is an open access article distributed under the Creative Commons Attribution License, which permits unrestricted use, distribution, and reproduction in any medium, provided the original work is properly cited

\section{Abstract}

We are reporting a case of a 14 months year-old boy with Fitzpatrick type 4 skin presented with multiple brownish skin lesions which started over the trunk and progressed to involve the face and limbs past six months.

Keywords: mastocytosis , urticaria pigmentosa , clinic and dermoscopic features.

We are reporting a case of a 14 months year-old boy with Fitzpatrick type 4 skin presented with multiple brownish skin lesions which started over the trunk and progressed to involve the face and limbs past six months. [Figure 1, 2, 3].

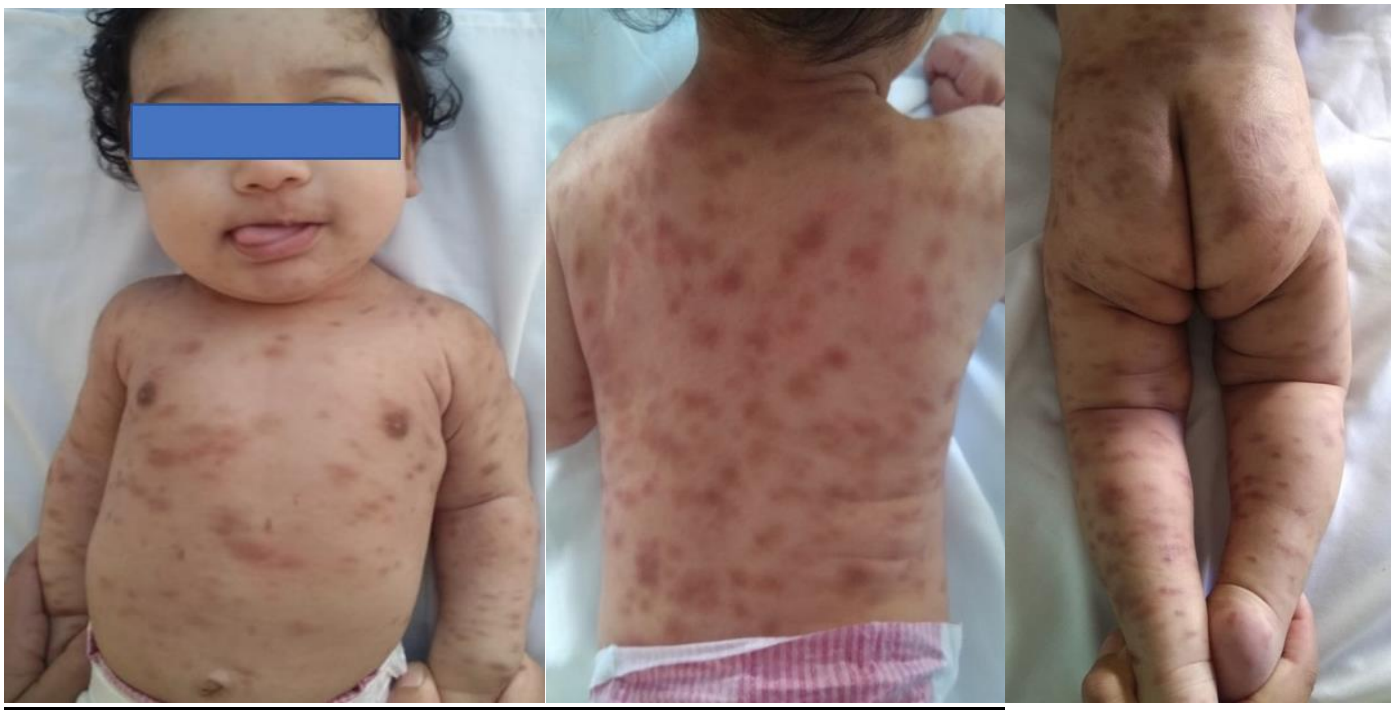

Figure 1, 2, 3 : Multiple hyperpigmented macules over face, trunk, back and extremities.

There was no family history of similar disease and the development of the child was normal. There was no history of urticarial flushing or bullae. On examination, there were multiple hyperpigmented macules over trunk, face, back and extremities. Gentle rubbing of the lesions elicited urtication and itching within 2 min and it resolved within 15-20 minutes, suggestive of the Darier's sign. [Figure 4] 


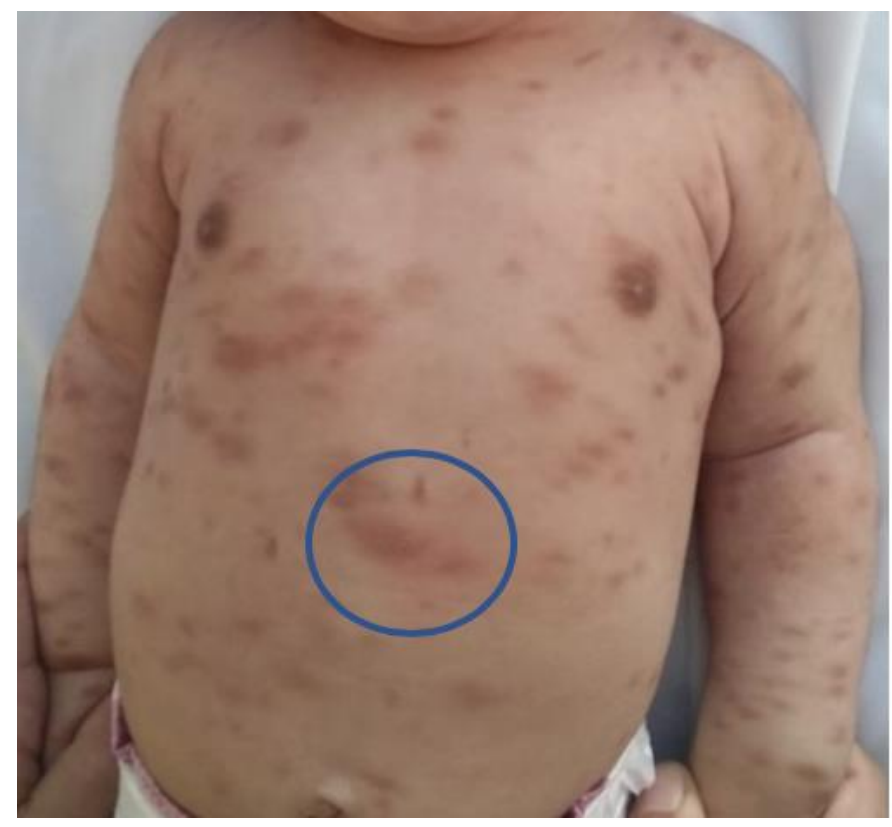

Figure 4: A positive Darier's sign ( encercled lesion)

Dermoscopy showed brownish reticular thick lines in the form of pigment network [Figure 5, 6].

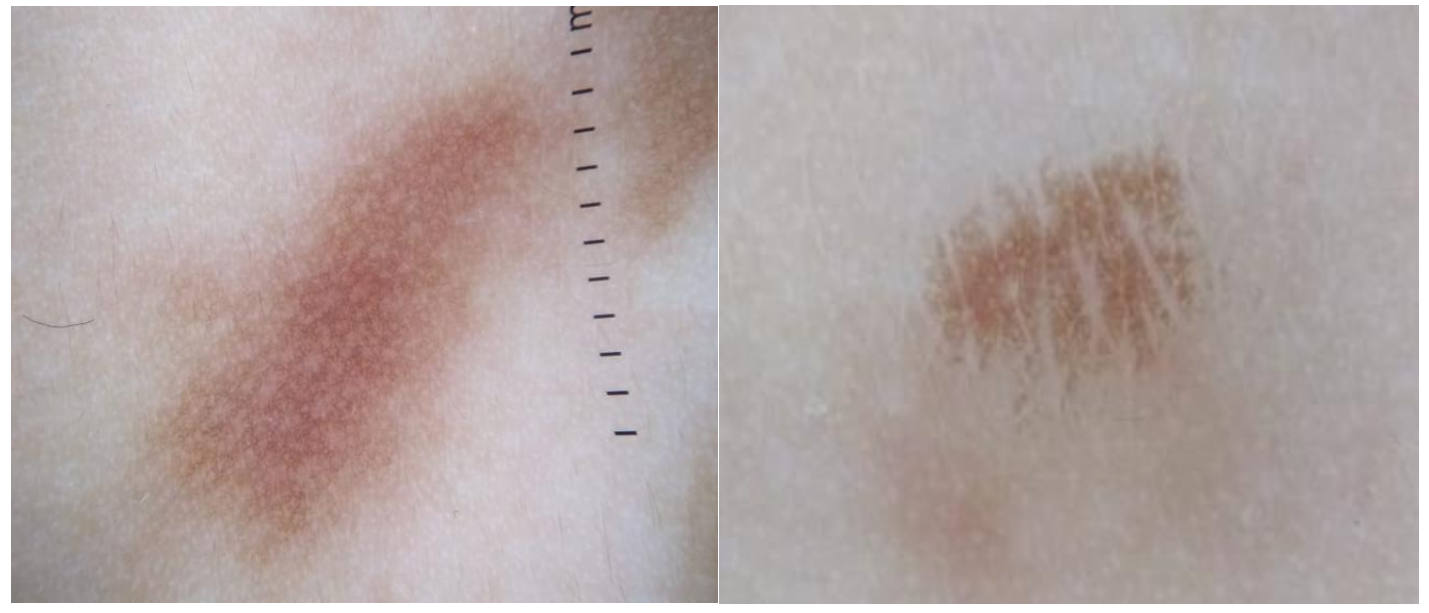

Figure 5 and 6: Exaggerated brown and thick reticulate pigment network (Dermlite DL4,3 Gen Inc, USA)

Histopathology of lesion over the back showed increased melanization of the basal layer with nests of oval mast cells infiltrating the upper and lower dermis with metachromatic granules visualized using toluidine blue stain diagnostic of urticaria pigmentosa.

Mastocytosis is a disorder characterized by accumulation and proliferation of mast cells in the skin, gastrointestinal tract, liver, spleen, lymph nodes, skeletal system, and bone marrow. According to the World Health Organization (WHO) consensus, mastocytosis in skin (MIS) is classified into three clinical variants: maculopapular, diffuse, and solitary mastocytoma. Maculopapular cutaneous mastocytosis is further subdivided into three types: urticaria pigmentosa, papular/plaque type, and telangiectasia macularis eruptive perstans. [1]

Urticaria pigmentosa is the most common form of mastocytosis that often develops in infancy or early childhood.
The lesions are rose colored, pruritic, urticarial, slightly pigmented macules, papules, or nodules. The nonevanescent urticated lesions persist and gradually become pigmented. The increased number of the functionally normal mast cells in the dermis degranulate in response to stroking with the release of histamine, which is responsible for the local itching, erythema, and weal formation or the Darier's sign. [2] The lesions usually disappear within a few years, usually before puberty, although in a few cases this lesions may persist into adult life. Although systemic involvement is possible, malignant transformation is exceedingly rare.

The dermoscopic patterns seen in various forms of cutaneous mastocytosis include: pigment network, reticular vascular pattern, yellow-orange blot, and light-brown blot. [3] Pigment network is a dermoscopic feature that is characteristic of melanocytic lesions. Non-melanocytic lesions like dermatofibroma, solar lentigo, seborrheic 
keratosis, accessory nipple, and even normal skin exhibits this dermoscopic feature.[4] Urticaria pigmentosa is an addition to the list of non-melanocytic lesions showing pigment network in dermoscopy. Factors secreted by mast cells induce proliferation of melanocytes and melanin production resulting in exaggeration of brown pigment network under dermoscopy.Hence, dermoscopy is a useful method to sub-classify mastocytosis and differentiate it from its close clinical mimics.

Declaration of interest: None.

\section{References:}

1. Heinze A, Kuemmet TJ, Chiu YE, Galbraith SS. (2017) Longitudinal study of pediatric urticariapigmentosa. Pediatr Dermatol.34:144 9.
2. Surjushe A, Jindal S, Gote P, Saple DG. Darier's sign. (2007) Indian J Dermatol Venereol Leprol.73:363 4.

3. Miller MDB, Nery NS, Gripp AC, Maceira JP, do Nascimento GM. (2013) Dermatoscopic finding of urticariapigmentosa. An Bras Dermatol.88:986 8 .

4. Vano Galvan S, Alvarez Twose I, De lasHeras E, Morgado JM, Matito A, Sánchez Muñoz L, et al. (2011) Dermoscopic features of skin lesions in patients with mastocytosis. Arch Dermatol.147:932 40.
This work is licensed under Creative Commons Attribution 4.0 License

To Submit Your Article Click Here: Submit Article

DOI:10.31579/2578-8949/63
Ready to submit your research? Choose Auctores and benefit from:

$$
\begin{aligned}
& \text { fast, convenient online submission } \\
& \text { rigorous peer review by experienced research in your field } \\
& \text { rapid publication on acceptance } \\
& \text { * authors retain copyrights } \\
& \text { * imique DOI for all articles } \\
& \text { immediate, unrestricted online access }
\end{aligned}
$$

At Auctores, research is always in progress.

Learn more https://www.auctoresonline.org/journals/dermatology-anddermatitis/article-in-press 